\title{
COLONIAL HERITAGE IN LATIN AMERICA: DAMNATIO MEMORIAE OR TRANSCULTURAL DIALOGUE?
}

Amélia Polónia*

Cátia Miriam Costa*

Resumo: A maneira como o passado é apropriado pelos atores contemporâneos está sujeita a múltiplas dinâmicas, envolvendo diferentes stakeholders e interpretações contestadas. O surgimento de uma indústria do património acrescenta uma variedade de atores ao debate, incluindo: decisores, arqueólogos, acadêmicos sociais e culturais, empresários e empresários; cada um com uma perspetiva diferente (FALSER \& JUNEJA, 2013: 1). Recentemente, as comunidades locais foram adicionadas a esses debates, já que alguns projetos envolvendo sítios históricos foram contestados ou falharam completamente. Uma parte considerável dos projetos patrimoniais estava associada a planos turísticos e impunha um grande número de visitantes a alguns locais considerados essenciais para as identidades dessas comunidades locais, às vezes desconsiderando suas memórias, significados simbólicos ou interpretações passadas. Alguns autores apontaram diversas questões em torno da herança colonial, principalmente vistas como resultado de um sistema colonial (STOLER, 2013: 2). Os discursos baseados em perspetivas coloniais e o fato de algumas instituições e património material estarem ainda associados à opressão e à dominação estrangeira (MCATACKNEY \& PALMER, 2016, p. 473) exacerbam esse processo. Como resultado temos uma difícil assimilação de alguns locais ou componentes desse património pelas comunidades atuais, que exigem o reconhecimento de identidades e valores autóctones. Uma

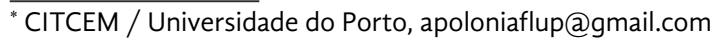

${ }^{*}$ CEI/ISCTE - Instituto Universitário de Lisboa, catia.miriam.costa@iscte-iul.pt Este artigo foi publicado originalmente em: SANTOS, Joaquim Rodrigues (ed.) - Preserving Transcultural Heritage: Your Way or My Way?. Casal de Cambra: Caleidoscópio, pp. 639-645.
} 
das razões para se recusar a aceitar essa herança é que o conceito de manter e preservar é bastante diferente do conceito ocidental de preservação do património. O primeiro inclui, por exemplo, a invasão de sítios históricos pela natureza (por exemplo, áreas edificadas de floresta) que podem ser aceites como um fim natural de um património construído que perdeu suas funções e abre espaço para novos usos práticos, incluindo a recuperação. os usos desse território em tempos pré-coloniais (LUCO, 2013: 256).

Palavras-chave: Herança Colonia; América Latina; CidadesPorto.

Abstract: How the past is appropriated by contemporary actors is subject to multiple dynamics, involving different stakeholders and contested interpretations. e emergence of a heritage industry adds a variety of actors to the debate, including decision-makers, archaeologists, social and cultural academics, businesspeople and entrepreneurs, each one with a different perspective (FALSER \& JUNEJA, 2013: 1). More recently, local communities were added to these debates as some projects involving heritage sites were contested or even failed altogether. A considerable part of the heritage projects was associated with touristic plans and imposed massive numbers of visitors to some places seen as essential to the identities of such local communities, at times disregarding their memories, symbolic meanings or past interpretations. Some authors have pointed out diverse issues around colonial heritage, mainly seen as the aftermath of a colonial system (STOLER, 2013: 2). Discourses based on colonial perspectives, and the fact that some institutions and material heritage are still associated with oppression and foreign domination, (MCATACKNEY \& PALMER, 2016: 473) exacerbate this process. The result is a difficult assimilation of some sites or components of that heritage by today's communities, calling for the recognition of autochthone identities and values. One of the reasons for refusing to accept this heritage is that the concept of keeping and preserving is rather different from the western concept of heritage preservation. e former includes, e.g., the invasion of heritage sites by nature (e.g., forest overgrowing built-up areas), that can be accepted as a natural ending of a built patrimony which lost its functions and makes room for new practical uses, including 
recovering the uses of that territory in pre-colonial times (LUCO, 2013: 256).

Keywords: Colonial Heritage; Latin America; Port Cities.

\section{Some Concepts}

Over and beyond the importance of material and immaterial heritage le by the colonizers, any discourse about colonial heritage also has to take into account the interpretation of pre-colonial heritage by the colonial authorities. In general, significantly builtup environments were recognized. In some cases, and due to the importance of their function and aesthetical value, the colonizers created national archaeological parks and heritage classification (FALSER \& JUNEDA, 2013: 88; BENAVIDES, 2013: 256), starting at the end of the 18th century (in connection with the Enlightenment, followed by scientific positivism) in some case until decolonization. But at the same time, the colonizers' dissociation between this precolonial heritage and the colonized populations during the period of colonial system was very clear, as if those patrimonies were not part of their own heritage. Not knowing how to read the pre-colonial monuments' inscriptions, not understanding the civilizations that produced them or having to rely on no more than an oral memory of their meanings was one of the reasons of the discrepancy between a recognized built space, due to its significance as a monument, and the actual incorporation of it as cultural heritage of the autochthone populations. Furthermore, the local communities' ignorance of the history of this patrimony was one of the arguments used to treat them as inferior. In so doing, colonial power not only built new heritage, it also classified and determined the significance or insignificance of the pre-colonial one.

Today, the more contentious issues relate to the heritage built in colonial times and associated with colonial aims, strategies, and domains. In fact, not only buildings, documents, and discourses lean imprint and negative memories on colonized communities. e organization of space, too, was sometimes a symbol of oppression and domain. Urbanized spaces were o often interpreted as a strong testimony of all negative aspects of colonialism (PARKINSON et 
al., 2016: 2). Even technology was seen as a tool for domination because its property and use were restricted to the representatives of the colonial order and worked in favor of a colonial economy. e replacement of colonial power by local governments not always meant the recognition of the role of local communities. Still, depending on the political interests of new elites, a part of this built heritage was considered as a testimony of dominance while another part was kept as a symbol of political power, now associated with local elites, that used it as representations of their own power.

In Latin America, when trying to build an idea of national integration, some of the most notable political leaders against colonialism tried to reconcile anti-colonialist principles with the recognition of colonial past, not rejecting all political, cultural and social heritage le by the colonial regime. One way of doing it was to create the idea of cultural and even biological blending, from which resulted phenomena and expressions of 'mestizaje/mestiçagem' (BAUER, 2013: 105-106). During the 19th century, the political idea of mixture/miscegenation was part of an important strategy to refuse US dominance after the decolonization process and to point out the difference between the recent independent countries, the colonizer and the North American hegemonic power (among these leaders, Simon Bolívar and José Martí).

This is quite a different context of the use of the concept of miscegenation, in the 20th century, by the colonizers themselves (see e.g. the use of the Brazilian sociologist, Gilberto Freyre's Lusotropicalism by Salazar regime, in the 1960's) (CASTELO, 1998). Postcolonial studies apply the same concept to the phenomena of intensive blending, mostly when applied to Latin America, arguing that colonial spaces and societies were not blank sheets where the Europeans wrote their histories or le their exclusive footprint. Theories of cooperation (which involve also ideas of negotiation, resistance, and confrontation) emphasized new ways of understanding colonialization and contributed to different processes of memorialization. Those theories recover the silent role of the autochthone population in the building of empires (ROBINSON, $1972,1986)$. Nowadays, this discourse of miscegenation is used by local communities themselves to claim their own right to heritage management and to political participation. Instead of a total refusal of colonial heritage, they stress their role during colonization, and 
deny they were excluded from the process of modernization of their countries, thus making the best use of globalization dynamics by boosting tourism. All this affects the concept, the idea and the uses of local heritage.

\section{Transcultural Places: Port Cities and Coastal Areas}

Coastal areas and port cities of Latin America raise a particular interest when approaching the question of colonial heritage and its interpretation. Seaports were the first and most continuous point of interface between continents, performing as exchange platforms. e connection with a vast hinterland developed from the coastline to the interior. Until the first decades of the 20th century, coastal areas and port-cities were the most dynamic in terms of urbanism and architecture, but also in political, social, demographic and economic terms. Port cities have some specific characteristics, such as a high level of economic, social and cultural exchanges, and the contact with broader and more distant realities. In some cases, the memory of this past dynamism is associated with negative features, like slavery or forced labor and the high-power asymmetry between the colonizer and the colonized. As a result, port-cities dynamics, memories and heritage have different signifiers, associated with the different memories each social group or individual carries with them.

Even though, there was an international movement to safeguard these cities. It began in Europe, the US, and Japan, but rapidly spread further. In the 1990s some Latin American cities joined this trend. La Habana (Cuba) and Santos (Brazil) were among the first port cities of this region to have a renewed historical center and a requalified seafront. In order to satisfy the inhabitants of those areas, access to leisure areas, green spaces and integration of those spaces into the urban perimeter were guaranteed by projects of urban intervention (HOYLE, 2002: 142). Even so, the risk of antagonizing the community is still high. Frequent exchanges with the community are required to make public powers and international institutions aware of their feelings about the transformation of the historical centers, and to identify which memories they associate with those places. Modernizing and 
creating better living conditions for communities are well received, but the acceptance decreases when other implications of those public and private investments interfere with individuals' everyday life. In some of these rehabilitated cities, massive tourism became a point of tension with the local community, who felt their space was being invaded and disrespected.

Recent studies based on interdisciplinary and transdisciplinary approaches indicate the need for bottom-up initiatives during the conception and implementation of those projects (PARKINSON et al., 2016: 2). e development of such work with the communities helps to gather shared opinions and to add new perspectives to the result (FALSER \& JUNEJA, 2013: 2). Obtaining community agreement on the interventions is expected to help stabilize the political and social dialogue, and to provide a better interpretation of projected or even on-going transformation processes. is requires local interventions and a permanent interaction with the communities, and implies multi-disciplinary teams using a wide variety of communication channels. Social scientists (sociologists, economists, psychologists) are required, but also well-prepared heritage technicians and managers, along with mediation agents able to connect the expectations of the population with urban and heritage policies. Those are no longer local, regional or national. e UNESCO classification of some of those sites implies the acknowledgment and observation of international rules, which asks for a full understanding of its meanings and requirements.

This leads to another dimension of the debate: the reinterpretation of colonial heritage in the light of a site's current status as a globalized city. It implies the city sees itself as an urban space, has its own international contacts, and develops a strategic public policy based on the significance of the cities as nonEuropean foundations of European imperialism in a globalized space (CURTIS, 2016: 1). An interesting study compared colonial heritage interpretations in Singapore and Jakarta. It concluded that the global public policy developed in Singapore, based on multiracialism, multireligious beliefs and multilingualism permitted an intervention on typical spaces connected with colonial heritage and gave them a new significance. As for Jakarta, tensions over the interpretation of colonial heritage went on, and it was di cult to change the memory of colonial spaces without provoking local objections (JONES \& SHAW, 
2006). is shows how today's profile of a community interferes with policies of memory and strategies of heritage preservation and classification by the communities and/or the public powers.

As social constructed places, cities have the challenge of dealing with the old and the new, and at the same time with facts and memories. Decision makers also have to take into account that memories and discourse are as important as material patrimony. Therefore, the involvement of local communities is essential for the success of any project affecting heritage, material and immaterial, tangible or intangible.

In most countries of Latin America, on-going heated debates require the participation of local populations in the planning and execution of heritage policies. In coastal areas and port-cities highly associated with colonial dominance and colonial heritage, while also being attractive centers for tourism and leisure, this becomes relevant, for two groups of reasons. First, for decades an uncritical acceptance of colonial heritage emerged, in an environment in which elites saw it as part of a political project of unification and international recognition of the new countries. Secondly because, in times during which heritage (natural, cultural, material and immaterial) has, notably in those countries, economic value, it is paramount to consider new policies to implement the integration of the common population as active economic actors and beneficiaries of those increasing dynamics of heritage economic uses.

As for the first topic, the rise of some nativist claims and the critical consciousness of colonial heritage is bringing up new ideas and pointing out new policies of memory. To clarify some of these issues it becomes necessary to study mobility (of people, ideas and goods), migrations and networking, which is permitted by the natural, social and political conditions of port cities. Likewise, the dialogue between the population, heritage technicians and stakeholders, needs to be initiated, without avoiding the controversial aspects of dealing with plural and sometimes conflictive memories. e well-known projects on colonial heritage of port cities and the current state-of-the-art literature are clear about the benefits of the connection between experts, policy makers, investors and local communities. Going deeper in our analysis we think we should complete this dialogue with vocational training of individuals and public awareness of the social and economic profits colonial 
heritage can offer. Only a shared and participative memory policy, and a pluralist recognition of material and immaterial patrimony can contribute to its preservation without dissatisfaction or a deep feeling of disrespect. A transcultural approach, over and beyond a multidisciplinary one, is required to allow new interpretations of the past, while trying to convert useless patrimony and negative memories into sites with new functions. Creative and cultural industries, new economic solutions and a permanent dialogue between academia and society can help to return these port cities to their previous calling as places of transcultural contact and openness to global trends, except this time considering, integrating and bene ting the local populations, which are and have been for centuries active heritage builders. The goal is to incorporate their voice into global dynamics of heritage preservation and socio-cultural and economic uses. By doing so, academics, policy-makers, and heritage managers have also a chance to reactivate silent presences and voices, which, being essential to the building of pre-colonial, colonial and post-colonial processes are hardly heard. Women, slaves, creole population, ethnic and religious minorities are just some of them, despite the current concern with slavery and the cultural marks of an Afro-Latin-American culture.

\section{A Project into Action}

Based on these concerns and practical considerations, a project, CoopMar, was put into action to implement some key-ideas:

1. New approaches are required to pursue innovative strategies for the management of coastal heritage in Europe and Latin America, resulting from transoceanic dynamics; and

2. This challenge encompasses a transnational and interdisciplinary approach and a plan of action incorporating environmental, social, economic, cultural and historical perspectives in a coherent framework for sustainable heritage management and socio-economic development.

CoopMar (Transoceanic Cooperation. Public Policies and 
Ibero-American Sociocultural Community) is a CYTED (Programa Ibero-Americano de Ciência e Tecnologia para o Desenvolvimento/ Ibero-American Program for Science and Technology for Development) network. CoopMar explores the relationship between sea and society, with a special focus on maritime and port cities' communities and heritage.

CoopMar prioritises knowledge circulation among stakeholders (universities, museums, foundations, firms, public institutions, and the broader society). Its general mission is to make an inventory of shared heritage in two European (Portugal and Spain) and four Latin American countries (Brazil, Cuba, Panama, and (Chile) and to offer scientific knowledge to societies, promoting genuine interaction and empowerment of Ibero-American port cities communities.

CoopMar is centered around the concept of a transnational and transdisciplinary knowledge society. It assumes the cooperative interchange of values and visions as an intangible infrastructure that works as a basic social capital bene ting key Port Cities in the IberoAmerican region. e public value of this, we believe, is yet to be fully realized.

The project aims at intensifying existing research linkages and create new ones across different scholarly and institutional actors; using new technologies and approaches for exploring new dimensions of the globalising maritime economy, including the creative industries; promoting a participative dialogue between countries, organisations and Port City communities; defining an action-plan for researchers, citizens, business people, and policymakers.

CoopMar's general mission is to deeply study shared memory and heritage so as to provide societies with scientific knowledge, promoting the genuine interaction and empowerment of IberoAmerican port city communities. For that, the team aims to develop strategic research concerning shared intangible resources in the Ibero-American region and to promote useful deliverables in the areas of social sustainability and heritage curation. In short, the final purpose of this network is to promote awareness in communities, to enhance a networked Port City sphere, and to deliver new public policy options. 
Beginning in 2017, the guidelines and strategies of the project will be submitted to public debate to incorporate new ideas and criticism in its plan of action.

\section{Why Choose Ibero-America?}

Port cities in Ibero-America and the Iberian Peninsula have a common history, which generated important common heritage, part of it classified as world cultural heritage. Most of those classified sites are a true example of mixing cultures, because of forced and free migrations, leading to a very rich heritage with tangible and intangible manifestations. e connections between the American and European world are also a source for new approaches to the built heritage but also to the shared memories, some of them bringing hard recalls of the past, because of slavery, indented labor, and coerced migrations, and of violent relations under colonial rule.

The tangible heritage has long been appreciated, and the International Council of Monuments and Sites (ICOMOS) is doing significant work in 108 countries around the world, including all countries involved in the CoopMar project. Recently, ICOMOS launched a Guidance on Post Trauma Recovery and Reconstruction for World Heritage Cultural Properties ${ }^{1}$ focused in areas destroyed by natural catastrophes and wars. Although none of our cases are in these categories, these countries were part of a colonial system which produced traumatic memories, still present in some monuments and heritage. ICOMOS has defended the technical intervention in built-up landscapes, through the best practices of conservation and restoration, but also moved its attention to other areas like human occupation and memories associated with constructed space.

In Chile, one of the countries partners of this project, Valparaíso as a cultural world heritage site has been one of the most interesting areas of intervention, and a place where important research has been developed. e main challenge was to reconcile the diverse stakeholders' interests in an urban project. They had a series of conferences led by specialists in heritage and urbanism,

1 http://openarchive.icomos.org/1763/7/ICOMOS\%20Guidance\%20on\%20Post\%20Trauma\%20Recovery\%20Working\%20Document-.pdf 
and developed scientific work, while simultaneously promoting campaigns such as 'Lugar Validoso', in 2001, trying to encourage the connection between local and traditional commerce and heritage use, or the 2002 campaign to maintain the characteristics of recovered buildings. In both cases, the idea was to promote the exchange of knowledge and activity between university, NGOs, public institutions and civil society. Some authors, like Fernando Vergara in his doctoral thesis (not yet published), defended a more profound involvement of the community as the only way to promote a true patrimonial preservation.

One of the most sensitive and less explored items of heritage preservation detected by CoopMar researchers was this lack of preparation for civil society intervention and the lack of attention given to intangible patrimony. So, this research network is very focused on training students, organizations, and technicians to promote the intervention of civil society in the protection of heritage, and in the sharing of outcomes resulting from the recognition of port cities as very specific urban spaces. For this purpose, CoopMar prepared some training courses based on academic knowledge exchange to create a best practice model for tangible/ intangible heritage. Any discourse about colonial heritage also must considered under contested or conflictual memory. 


\section{Bibliography}

BAUER, Daniel E. (2012) - Emergent Identity, Cultural Heritage, and El Mestizaje: Notes from the Ecuadorian Coast. «Journal of Latin American Cultural Studies», vol. 21, no 1, pp. 103-121.

CASTELO, Cláudia (1998) - O Modo Português de Estar no Mundo. O Luso-Tropicalismo e a Ideologia Colonial Portuguesa (19331961). Lisboa: Bertrand.

BENAVIDES, O. Hugo (2013) - Working/Touring the Past: Latin American Identity and the Political Frustration of Heritage. «International Journal History and Archaeology», vol. 17, $\mathrm{n}^{\circ} 2$, pp. 245-260.

CORBETT, Jack; VEENENDAAL, Wounter (2016) - Westminster in Small States: Comparing the Caribbean and Pacific Experience. «Contemporary Politics», vol. 22, n 4, pp. 432-449.

CURTIS, Simon (2016) - Global Cities and Global Order. Oxford: Oxford University Press.

FALSER, Michael; JUNEJA, Monica (eds.) (2013) - Archaeologizing” Heritage? Transcultural Entanglements between Local Social Practices and Global Virtual Realities. Berlin \& Heidelberg: Springer.

FERRADA AGUILAR, Mario; UNDURRAGA CASTELBLANCO, Paz (2016) - Patrimonio Arquitectónico de Valparaíso. Del des-criterio a la Innovación Criteriosa. «International Journal History and Archaeology», vol. 20, n³, pp. 601-613.

HOYLE, Brian (2002) - Urban Waterfront Revitalization in Developing Countries: The Example of Zanzibar's Stone Town. «Geographical Journal», vol. 168, n² 2, pp. 141-162.

ICOMOS (2017) - ICOMOS Guidance on Post Trauma Recovery and Reconstruction for World Heritage Cultural Properties. Disponível em <http:// http://openarchive.icomos.org/1763/7/ ICOMOS\%20Guidance\%20on\%20Post\%20Trauma\%20Recovery\%20Working\%20Document-.pdf >.

JONES, Roy; SHAW, Brian J. (2006) - Palimpsests of Progress: Erasing the Past and Rewriting the Future in Developing Societies - Case Studies of Singapore and Jakarta. «International Journal of Heritage Studies», vol. 12, n² 2, pp. 122-138.

MCATACKNEY, Laura; PALMER, Russel (2016) - Colonial Institutions: Uses, Subversions, and Material Afterlives. «International Journal History and Archaeology», vol. 20, n³, pp. 471-476.

PARKINSON, Arthur; SCOTT, Mark e; REDMOND, Declan (2016) Revalorizing Colonial Era Architecture and Townscape Legacies: Memory, Identity and Place-making in Irish Towns. "Journal of Urban Design», pp. 1-18. 
ROBINSON, Ronald (1986) - The Eccentric Idea of Imperialism, With or Without Empire. In MOMMSEN, W. J.; OSTERHAMMEL, J. (eds.) - Imperialism and After. Continuities and Discontinuities. London: Allen and Unwin, pp. 267-289.

(1972) - Non-European Foundations of European Imperialism: Sketch for a Theory of Collaboration. In OWEN, R.; SUTCLIFFE, B. (eds.) - Studies in the Theory of Imperialism. London: Longman, pp. 117-142.

STOLER, Ann Laura (ed.) (2013) - Imperial Debris. On Ruins and Ruination. Durham \& London: Duke University Press. (2009) - Along the Archival Grain: Epistemic Anxieties and Colonial Common Sense. Princeton: Princeton University Press.

UNDURRAGA CASTELBLANCO, Paz (2010) - Modelo de "Recuperacion Patrimonial en Valparaíso. Paper apresentado na Conferência Riesgos y Desafíos de los Dispositivos de Intervención. 
